J. Clin. Chem. Clin. Biochem.

Vol. 20, 1982, pp. 615-619

\title{
Urinary Excretion of Alanine Aminopeptidase and N-Acetyl- $\beta$-D-Glucosaminidase During Sequential Combination Chemotherapy ${ }^{1}$ )
}

By U. Diener, E. Knoll, D. Ratge

Department of Clinical Chemistry, Robert-Bosch-Krankenhaus, Stuttgart (F.R.G.)

\section{B. Langer}

Department of Haematology, Immunology and Oncology, Robert-Bosch-Krankenhaus, Stuttgart (F.R.G.) and

H. Wisser

Department of Clinical Chemistry, Robert-Bosch-Krankenhaus, Stuttgart (F.R.G.)

(Received December 14, 1981/April 16, 1982)

Summary: The urinary excretion of alanine aminopeptidase (EC 3.4.11.2) and N-acetyl- $\beta-D$-glucosaminidase (EC 3.2.1.30) was determined in 23 patients with testicular cancer during sequential combination chemotherapy with vinblastine/bleomycin and doxorubicin/cis-platinum. Increases in enzyme excretion were more often noticed during therapy with vinblastine/bleomycin than with doxorubicin/cis-platinum. Moreover, the rises during vinblastine/ bleomycin therapy were more pronounced. The enzyme activities varied from the normal range up to the 14-fold of the upper limit of the normal range. With few exceptions, enzyme excretions returned to normal or slightly elevated values before the subsequent course. No renal insufficiency could be detected with the commonly used parameters of renal function such as serum creatinine concentrations and creatinine clearance values, which were determined at irregular intervals. Ausscheidung von Alaninaminopeptidase und $N$-Acetyl- $\beta-D$-glucosaminidase im Harn während sequentiell alternierender
Chemotherapie

Zusammenfassung: Bei 23 Patienten mit Hodenkarzinomen wurde die Ausscheidung von Alaninaminopeptidase (EC 3.4.11 .2) und der N-Acetyl- $\beta$-D-glucosaminidase (EC 3.2.1.30) im Ham während der sequentiell alternierenden Chemotherapie mit Vinblastin/Bleomycin und Doxorubicin/Cisplatin gemessen. Dabei wurde festgestellt, daß Enzymanstiege unter Vinblastin/Bleomycin-Gabe häufiger auftraten und deutlicher ausgeprägt waren als unter der Doxorubicin/Cisplatin-Behandlung. Die Alaninaminopeptidase- und N-Acetyl- $\beta-D$-glucosaminidase-Ausscheidungen erreichten Werte bis zum 14-fachen der oberen Normbereichsgrenze. Bis auf wenige Ausnahmen lagen die Werte der Enzymausscheidungen zu Beginn eines neuen Therapiezyklus wieder im Normalbereich oder waren nur geringfügig erhöht. Die in unregelmäßigen Zeitabständen ermittelten Kreatininkonzentrationen im Serum und Kreatininclearancewerte ergaben keinen Hinweis auf eine Niereninsuffizienz während der Therapie.

\section{Introduction}

Determination of urinary enzyme excretion has become a recognized aid in diagnosis and monitoring of drug nephrotoxicity $(1,2)$. Increases in enzyme activities have been demonstrated before elevations in serum urea and

\footnotetext{
1) This study was supported by the Robert Bosch Stiftung, Stuttgart (F.R.G.)
}

serum creatinine $(3,4,5)$. Therefore changes in urinary enzyme output are an early sign of alteration or damage to the kidney tubules. It is not always possible to decide if there is a direct or secondary effect of the drug on the tubule.

Nephrotoxicity is one of the major complications during therapy with the cytostatic drug cis-platinum. In previous studies it could be demonstrated that during and 
after therapy with cis-platinum - alone or in combination with other drugs - the urinary enzyme activities were elevated $(3,4,6,7)$. In these studies the patients received in most cases a single high dose of cis-platinum during one therapy course. One aim of this trial was the examination of the response of the enzymes during the administration of cis-platinum in a low dose once a day for five days. Cis-platinum was part of a sequential combination chemotherapy with vinblastine/bleomycin and doxorubicin/cis-platinum. All patients, who received this therapy, had testicular cancer. For our investigations we chose the brush border enzyme alanine aminopeptidase (EC 3.4.11.2) and the lysosomal enzyme $\mathrm{N}$-acetyl $-\beta-D$ glucosaminidase (EC 3.2.1.30). The simultaneous determination of the two enzymes - each of different origin - might permit conclusions on the localization of renal damage or on the different mechanism of action of the drugs in the same part of the tubules. Furthermore, it should be possible to show whether enzymurias if at all detectable - are reversible. Another point of this investigation was a comparison of the enzyme excretion during courses with vinblastine/bleomycin before and after the administration of doxorubicin/cis-platinum in order to establish an eventual influence of doxorubicin/cis-platinum on the enzyme excretion during the therapy with vinblastine/bleomycin.

\section{Methods}

The enzyme activities were determined in 3-h urine samples which were collected from 7 to $10 \mathrm{a} . \mathrm{m}$. The constant sampling time should eliminate influences of any circadian rhythm (8). Storage in a refrigerator at $6{ }^{\circ} \mathrm{C}$ proved to be the best method of maintaining constant enzyme activities $(3,9)$. The determinations of alanine aminopeptidase and $N$-acetyl- $\beta$ - $D$-glucosaminidase were carried out as described in detail by Diener et al. (3) and Knoll et al. (9). Urinary enzyme activities were expressed as units per mmol of urinary creatinine, in order to eliminate the influences of variable diuresis.

Reference range of alanine aminopeptidase excretion (3):

Females: (18-55 years): $0.24-0.55 \mathrm{U} / \mathrm{mmol}$ creatinine median: $0.42 \mathrm{U} / \mathrm{mmol}$ creatinine.

Males: $\quad$ (8-46 years): $0.32-0.75 \mathrm{U} / \mathrm{mmol}$ creatinine median: $0.54 \mathrm{U} / \mathrm{mmol}$ creatinine.

Reference range of $\mathrm{N}$-acetyl- $\beta$ - $D$-glucosaminidase excretion (8):

Females: $0.27-1.18 \mathrm{U} / \mathrm{mmol}$ creatinine - median: $0.57 \mathrm{U} / \mathrm{mmol}$ creatinine.

Males: $\quad 0.19-1.06 \mathrm{U} / \mathrm{mmol}$ creatinine - median: $0.46 \mathrm{U} / \mathrm{mmol}$ creatinine.

As urinary enzyme activities - expressed as units per mmol of urinary creatinine - had been determined at different temperatures they were standardized by dividing by the upper limit of the normal range. Creatinine was measured in serum and urine by a modified Jaffé method (10). During some therapy courses with doxorubicin/cis-platinum the urinary protein patterns were determined with the aid of high performance gel permeation chromatography (11).

\section{Patients and therapy}

23 patients with testicular cancer were entered in this study.

The average age was 30 years, ranging from $16-47$ years. In some cases the carcinomas were disseminated. 17 patients had non- seminomatous carcinomas. Six patients had nonseminomatous carcinomas with seminomatous elements. After orchiectomy and in some cases retroperitoneal lymphadenectomy some patients received an adjuvant therapy and the others a remissioninduction therapy. The treatment consists of a sequential combination chemotherapy with vinblastine/bleomycin and doxorubicin/cis-platinum according to Scheulen et al. (12). The plan of treatment is shown in table 1 .

Tab. 1. Plan of treatment (11).

Time interval: adjuvant therapy: normally 28 days; induction therapy: normally 21 days.

Regimen I: $\quad$ vinblastine: $0.2 \mathrm{mg} / \mathrm{kg} \times \mathrm{d}$ on day 1 and 2; bleomycin: $30 \mathrm{mg} / \mathrm{d}$ on day 1 to 5 .

Regimen II: doxorubicin: $50 \mathrm{mg} / \mathrm{m}^{2}$ on day 1 ; cis-platinum: $20 \mathrm{mg} / \mathrm{m}^{2} \times \mathrm{d}$ on day 1 to 5 .

\begin{tabular}{llc}
\hline Adjuvant therapy & Course & $\begin{array}{l}\text { Remission-induction } \\
\text { therapy }\end{array}$ \\
\hline I & 1 & I \\
I & 2 & I \\
II & 3 & II \\
II & 4 & II \\
I & 5 & $\begin{array}{l}\text { etc. for a minimum of } \\
\text { courses in } \\
\text { complete responders }\end{array}$ \\
II & 6 &
\end{tabular}

Whenever complete response could not be achieved, alternative chemotherapy combination with ifosfamide plus etoposide was applied. 21 patients received courses of vinblastine/ bleomycin and 18 patients courses of doxorubicin/cisplatinum. 48 courses of regimen I and 44 courses of regimen II were evaluated.

During therapy no patient showed bacteriuria. Therefore infectious kidney diseases could not be the cause of possible increases in enzyme excretion in the course of cytostatic therapy.

\section{Results}

\section{Vinblastine/bleomycin (regimen I)}

Serum creatinine concentrations and creatinine clearance values - determined at irregular intervals - were within the reference range during therapy. The minimal enzyme excretions at the beginning of the courses and the maximal excretions during therapy are shown in figure 1. Only in four cases the pre-treatment values were elevated above the 2-fold of the upper limit of the normal range. During therapy the excretions of both enzymes increased. In $38 \%$ of the courses the alanine aminopeptidase values and in $48 \%$ of the courses the $\mathrm{N}$-acetyl- $\beta-D$. glucosaminidase values were not higher than the 2-fold of the upper limit of the normal range (tab. 2). Alanine aminopeptidase excretion was elevated above the 6 -fold of the upper limit during three courses (6\%); whereas $\mathrm{N}$-acetyl- $\beta-D$-glucosaminidase excretion was higher than the 6-fold during eight courses (16\%): In some patients the enzyme activities decreased during therapy. If the pre-treatment values were elevated, the excretion of both enzymes increased strongly during the courses. 


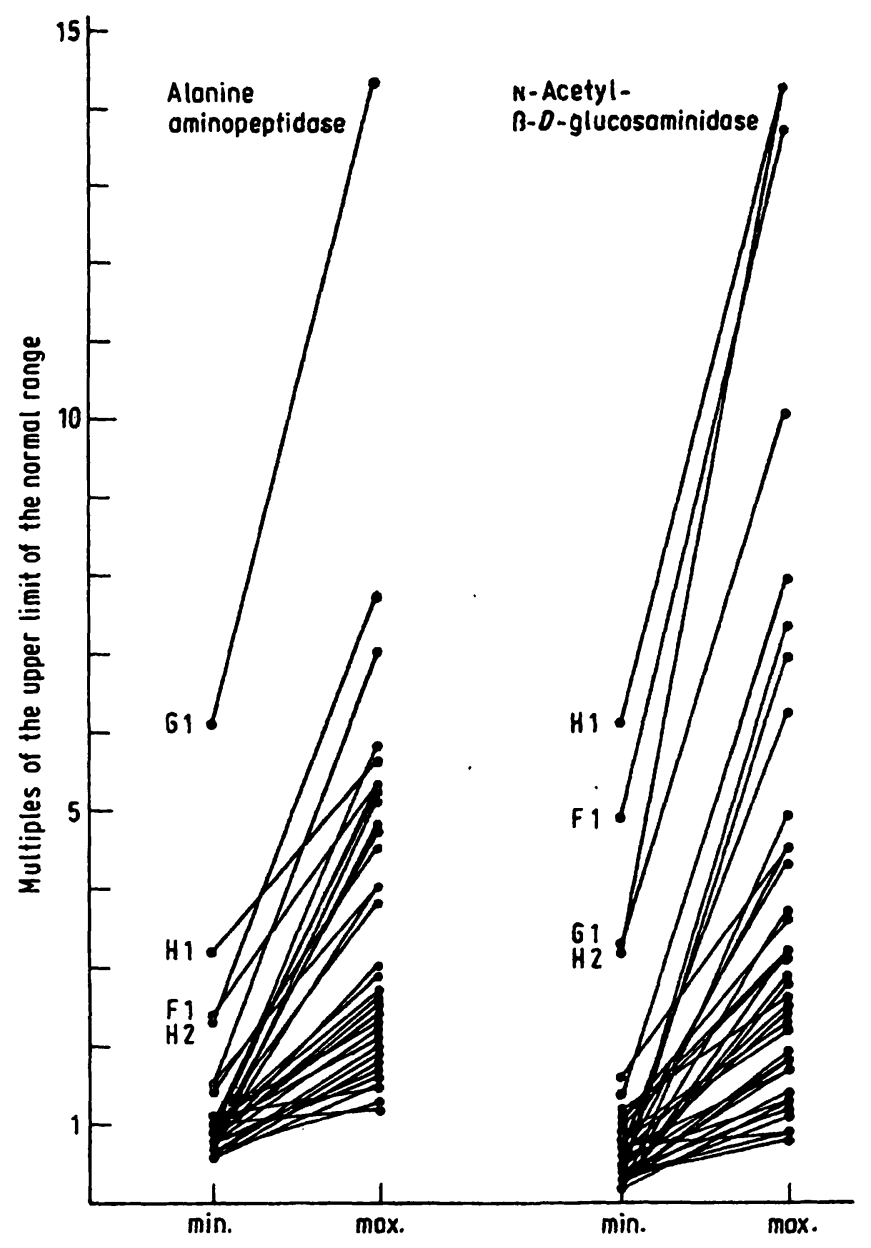

Fig. 1. Urinary enzyme activities at the beginning of the course ( $\min$ ) and the maximal values (max.) during therapy with vinblastine/bleomycin. (F 1 = patient $F$, course 1 etc.)
Tab. 2. Percentage distribution of the maximal enzyme activities (regimen I = vinblastine/bleomycin; regimen II = doxorubicin/cis-platinum.

\begin{tabular}{|c|c|c|c|c|}
\hline \multirow{2}{*}{$\begin{array}{l}\text { Multiples of } \\
\text { the upper } \\
\text { limit of the } \\
\text { normal range }\end{array}$} & \multicolumn{2}{|c|}{$\begin{array}{l}\text { Alanine } \\
\text { aminopeptidase }\end{array}$} & \multicolumn{2}{|c|}{$\begin{array}{l}N \text {-Acetyl- } \\
\beta-D \text {-glucosaminidase }\end{array}$} \\
\hline & $\begin{array}{l}\text { regimen I } \\
\%\end{array}$ & $\begin{array}{l}\text { regimen II } \\
\%\end{array}$ & $\begin{array}{l}\text { regimen I } \\
\%\end{array}$ & $\begin{array}{l}\text { regimen II } \\
\%\end{array}$ \\
\hline$<2.0$ & 38 & 80 & 48 & 78 \\
\hline $2.0-5.9$ & 56 & 20 & 36 & 20 \\
\hline $6.0-9.9$ & 4 & - & 8 & 2 \\
\hline$>10.0$ & 2 & - & 8 & - \\
\hline$\Sigma>2.0$ & 62 & 20 & 52 & 22 \\
\hline
\end{tabular}

Elevated enzyme activities above the 3-fold of the upper limit of the normal range were always noticed in the same patients. This is demonstrated in table 3 which contains the results of the enzyme excretion of five patients with adjuvant therapy (three times regimen I and three times regimen II). These patients were selected because all their courses could be evaluated. The excretion patterns of the patients $A, B$ and $D$ are shown in figure 2 .

\section{Doxorubicin/cis-pla tinum (regimen II)}

The serum creatinine concentrations and creatinine clearance values - determined at irregular intervals were within the reference range just like during the therapy with vinblastine/bleomycin. As shown in

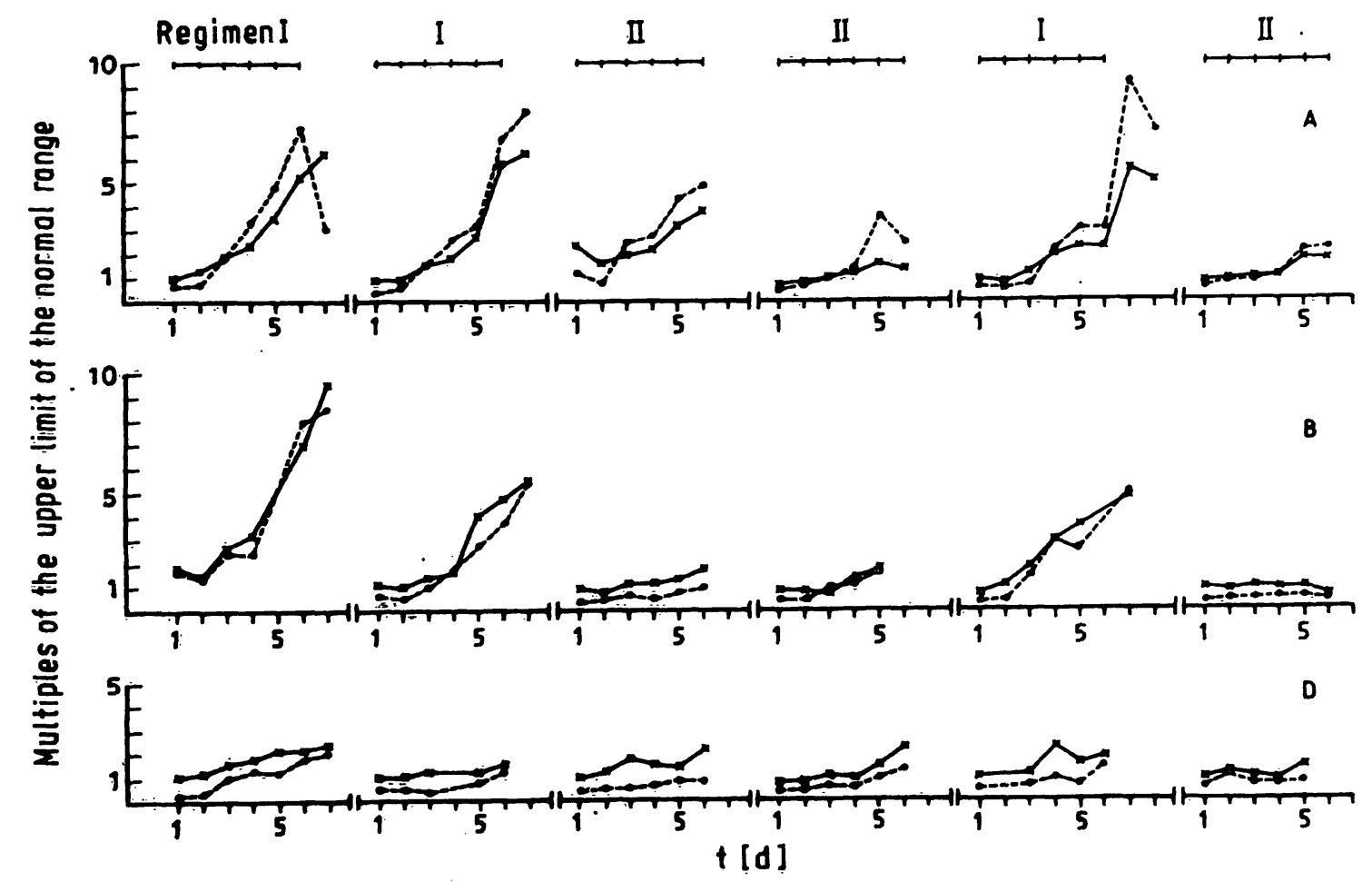

Fig. 2. Urinary excretion pattern of alanine aminopeptidase and $\mathrm{N}$-acetyl- $\beta$ - $D$-glucosaminidase during adjuvant therapy in patients $A$, $B$ and $D$. In course 5 patient $A$ received vinblastine on day 1 and 2 and bleomycin on day 3 to 7 . ( $x-x$, alanine aminopeptidase; - - $\mathrm{N}$-acetyl- $\beta$-D-glucosaminidase; regimen I = vinblastine/bleomycin; regimen II = doxorubicin/cis-platinum). 
figure 3, the pre-treatment values of the enzyme excretions were - with one exception - lower than the 2-fold of the upper limit of the normal range. In contrast to the courses with regimen I, the enzyme activities of alanine aminopeptidase and $\mathrm{N}$-acetyl- $\beta$ $D$-glucosaminidase increased above the 2 -fold of the upper limit in only approx. $20 \%$ of the courses (tab. 2). In one course, the maximal value was higher than the 6-fold of the upper limit of the normal range. In this patient, the pre-treatment value was elevated.

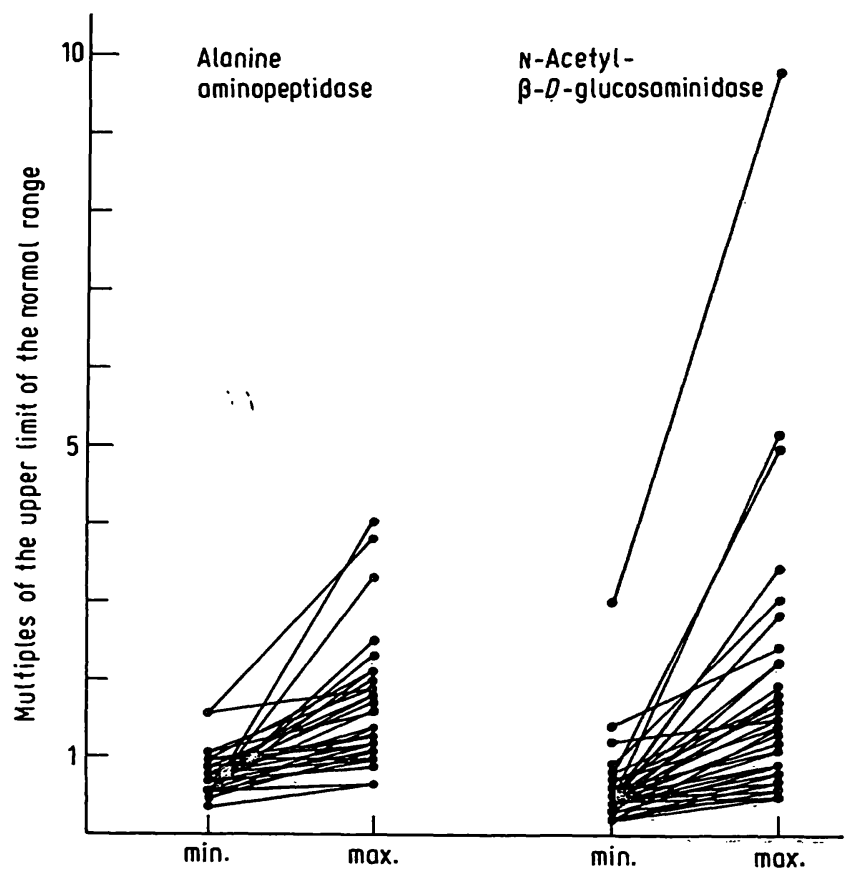

Fig. 3. Urinary enzyme activities at the beginning of the course (min.) and the maximal values (max.) during therapy with doxorubicin/cis-platinum.

Tab. 3. Number of courses with enzyme excretion above the three-fold of the upper limit of the normal range in five patients during adjuvant therapy (regimen $I=$ vinblastine/bleomycin; regimen II = doxorubicin/cisplatinum; AAP = alanine aminopeptidase; $\mathrm{NAG}=$ $\mathrm{N}$-acetyl- $\beta$ - $D$-glucosaminidase).

\begin{tabular}{|c|c|c|c|c|c|c|}
\hline \multirow{3}{*}{ Patient } & \multicolumn{3}{|c|}{ Regimen I } & \multicolumn{3}{|c|}{ Regimen II } \\
\hline & \multirow{2}{*}{$\begin{array}{l}\text { Total } \\
\text { number } \\
\text { of } \\
\text { courses }\end{array}$} & \multicolumn{2}{|c|}{$\begin{array}{l}\text { Number of } \\
\text { courses with } \\
\text { elevated values }\end{array}$} & \multirow{2}{*}{$\begin{array}{l}\text { Total } \\
\text { number } \\
\text { of } \\
\text { courses }\end{array}$} & \multicolumn{2}{|c|}{$\begin{array}{l}\text { Number of } \\
\text { courses with } \\
\text { elevated values }\end{array}$} \\
\hline & & AAP & NAG & & AAP & NAG \\
\hline 1) $\mathrm{A}$ & 3 & 3 & 3 & 3 & 1 & 2 \\
\hline B & 3 & 3 & 3 & 3 & 0 & 0 \\
\hline C & 3 & 3 & 1 & 3 & 0 & 0 \\
\hline D & 3 & 0 & 0 & 3 & 0 & 0 \\
\hline $\mathbf{E}$ & 3 & 0 & 0 & 3 & 0 & 0 \\
\hline
\end{tabular}

$\left.{ }^{1}\right)$ In course number 5 this patient received - contrary to the normal schedule - vinblastine on day 1 and 2 and bleomycin on day 3 to 7 . The values of this course were not considered in the other results.
Increases were noticed particularly in those patients who had raised enzyme activities during treatment with vinblastine/bleomycin (tab. 3). The urinary protein pattern was determined for a single course from each of five patients. There was a good correlation between enzyme excretion and protein'pattern. No pathological proteinuria could be detected whenever the enzyme excretion was normal. However, in the course of other investigations with patients receiving a single high dose of cis-platinum $\left(100 \mathrm{mg} / \mathrm{m}^{2}\right)$ this relationship could not be established. These patients showed large interindividual differences in the excretion pattern of proteins during increased enzyme excretion.

\section{Discussion}

As shown in table 2, more increases in enzyme excretion could be seen during therapy with vinblastine/bleomycin than during administration of doxorubicin/cis-platinum. In addition, the increases were more pronounced. Elevated enzyme excretions during therapy with vinblastine/bleomycin occurred before as well as after the courses with doxorubicin/cis-platinum. Thus an influence of the latter drug combination could almost completely be excluded. This conclusion is supported by the fact that the pre-treatment values of the courses with bleomycin following the administration of doxorubicin/cis-platinum were within the normal range or only slightly increased. The four elevated pre-treatment values at the beginning of the therapy with vinblastine/bleomycin (fig. 1) could be seen in the two courses before patients had received the first administration of doxorubicin/cis=platinum. The elevated enzyme activities at the beginning of the chemotherapy could be a result of the orchiectomy, which had been made seven to 17 days beffore. Thus, several authors $(13,14)$ described increased urinary enzyme excretions as a result of extrarenal causes, e.g. those occurring during and after operations. Thus, we demonstrated elevated activities of both enzymes after a gastric resection and a resection of a carcinoma of the rectum, with enzyme excretion increasing up to the 5 -fold of the upper limit of the normal range (fig. 4). A further indication of a reduction of renal function before the first administration of cytostatics shows the course of the enzyme excretion of patient $G$ during the remissioninduction therapy. At the beginning of the first course, he had elevated values of alanine aminopeptidase (8-fold) and $\mathrm{N}$-acetyl- $\beta$ - $D$-glucosaminidase (3.5-fold) which increased during the course up to the 14 fold (alanine aminopeptidase) and 10-fold (N-acetyl- $\beta$ - $D$ glucosaminidase) of the upper limit of the normal range. In all subsequent coursès the maximal values of alanine aminopeptidase and $\mathrm{N}$-acetyl $-\beta$ - $\tilde{D}$-glucosaminidase activities were below the 2-fold of the upper limit of the normal range. A comparison between the excretion pattern during administration of vinblastine/bleomycin and doxorubicin/cis-platinum in this investigation and 
the pattern during therapy with cis-platinum or aminoglycoside previousily described (3) show that the course of the excretion of both enzymes during vinblastine/ bleomycin is similar to that during doxorubicin/cisplatinum or cis-platinum, respectively. The similar excretion patterns might be an indication of the same point of attack of the drugs. However, it must be

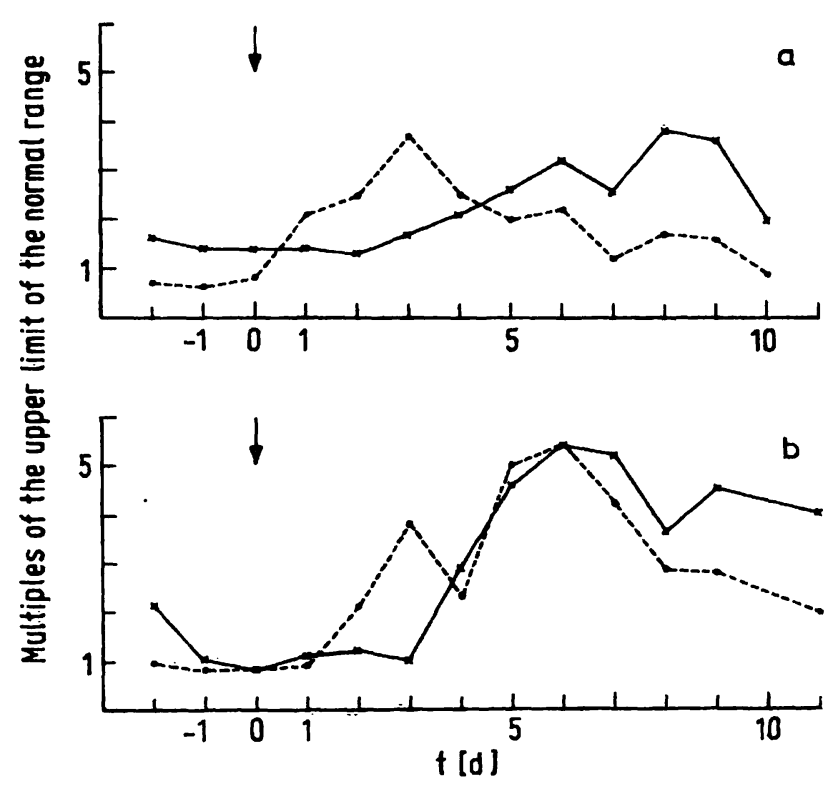

Fig. 4. Urinary excretion pattern of alanine aminopeptidase and $\mathrm{N}$-acetyl- $\beta-D$-glucosaminidase before and after operations. $(x-x$, alanine aminopeptidase; $\bullet-\ldots, \mathrm{N}$-acetyl $-\beta-D$. glucosaminidase. The arrows indicate the days of operation.)
a) male patient (66 years); gastric resection;
b) female patient ( 70 years); resection of a carcinoma of the rectum.

mentioned that the exact mechanism of action of vinblastine and bleomycin remains to be investigated. Up to now it is not possible to decide whether the enzymurias were caused by a direct effect of the drugs on the tubular cells or by an extrarenally produced tubular damage. The problem of nephrotoxicity of vinblastine and bleomycin will have to be solved in animal experiments. As far as permitted by the present studies, a cumulative nephrotoxic effect of vinblastine/ bleomycin on the subsequent courses was shown to be unlikely. With one exception (fig. 1; patient H., course 2) the pre-treatment values of the following courses were within the normal range or only slightly elevated. The reasons for the normalization of the enzymurias might be due both to the distribution of the total dosis of bleomycin and cis-platinum on several days during simultaneous diuresis and the great time interval between the courses. Furthermore, the turnover of tubular epithelial cells might speed up the excretion of the drugs or their metabolites during the intervals. However, if a few days after the end of the course a treatment with antibiotics in the leukopenic phase were necessary, a cumulative nephrotoxic effect might occur. This speculation is supported by our own investigations (in preparation). During the administration of gentamicin and ticarcillin in the leukopenic phase a further strong increase of enzyme activities could be demonstrated. To sum up, tubular alterations - detected by enzymurias - were not only noticed in patients receiving the nephrotoxic drug cis-platinum but also in patients receiving vinblastine/bleomycin. Cumulative nephrotoxicity can normally not be observed if the time intervals between the courses are at least as long as in this plan of treatment.

\section{References}

1. Dubach, U. C. \& Schmidt, U. (eds.) (1979) Diagnostic significance of enzymes and proteins in urine. Hans Huber Publishers, Bern, Stuttgart, Vienna.

2. Vanderlinde, R. E. (1981) Ann. Clin. Lab. Sçi. 11, 189-201.

3. Diener, U., Knoll, E., Langer, B., Rautenstrauch, H., Ratge, D. \& Wisser, H. (1981) Clin. Chim. Acta 112, 149-157.

4. Kuhn, J. A., Argy, W. P., Rakowski, T. A., Moriarty, J. K., Schreiner, G. E. \& Schein, P. S. (1980) Cancer Treat. Rep. $64,1083-1086$.

5. Sethi, K. \& Diamond, L. H. (1981) Nephron 27, 265-270.

6. Jones, B. R., Bhalla, B. S., Mladek, J., Kahuja, R. N., Gralla, R. J., Alcock, N. W., Schwartz, M. K., Young, C. W. \& Reidenberg, M. M. (1980) Clin. Pharmacol. Ther. 27, $557-562$.

7. Mitrou, P. S. \& Mondorf, W. (1980) in: Cisplatin: Derzeitiger Stand und neue Entwicklungen in der Chemotherapie malginer Neoplasien (Seeber, S., Schmidt, C. G., Nagel, G. \& Achterrath, W., eds.) pp. 34-44, S. Karger, Basel, Mächen, Paris, London, New York, Sydney.
8. Maruhn, D., Fuchs, I., Mues, G. \& Bock, K. D. (1976) Clin. Chem. 22, 1567-1574.

9. Knoll, E., Wisser, H. \& Rautenstrauch, H. (1980) this J. 18, 53-58.

10. Knoll, E., Rebel, F. C. \& Wisser, H. (1978) this J. 16, 239-244.

11. Ratge, D. \& Wisser, H. (1982) Urinary protein profiling by high performance gel permeation chromatography. J. Chromatogr. (in press)

12. Scheulen, M. E., Higi, M., Schilcher, R. B., Meier, C. R. Seeber, S. \& Schmidt, C. G. (1980) Klin. Wochenschr. S8, 811-821.

13. Burchardt, U., Peters, J. E., Neef, L., Thulin, H., Gründing, C. A. \& Haschen, R. J. (1977) Z. Med. Lab. Diagn. 18 , 190-212.

14. Raab, W. (1971) this J. 9, 143-154.
Dr. U. Diener

Abt. f. Klinische Chemie Zentrallabor

Robert-Bosch-Krankenhaus

Auerbachstr. 10

D-7000 Stuttgart 50 
$\cdot$ 